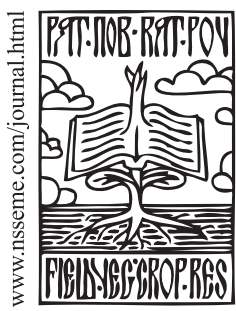

\title{
Allelopathic Effect of Aqueous Extract from Root Systems of Johnson Grass on Seed Germination and Initial Development of Soybean, Pea and Vetch
}

\author{
Shteliyana Kalinova • Irena Golubinova • Angel Hristoskov • Anna Ilieva
}

\author{
received: 15 November 2011, accepted: 10 September 2012 \\ (C) 2012 IFVC \\ doi: $10.5937 /$ ratpov49-1200
}

\begin{abstract}
Summary: This paper presents the results of the research on allelopathic effect of cold aqueous extracts from root systems of Johnson grass (Sorghum halepense (L.) Pers.) on the seed germination and the initial development of soybean (Glycine max (L.)), pea (Pisum sativum (L.)) and vetch (Vicia sativa (L.)) under laboratory conditions. It was established that the inhibitory effect of aqueous root extracts on the seed germination of soybean, peas and vetch varied between 28.8 and $86.3 \%$. Furthermore, the inhibitory effect of aqueous root extracts of Johnson grass varied between 17.1 and $86.1 \%$ on the development of the initial germ and between $8.3 \%$ and $97.9 \%$ on the accumulation of fresh biomass in the initial germ of soybean, peas and vetch. The values of $\mathrm{LC}_{50(\mathrm{P}=0.05)}$ were established to vary between 46.40 and $98.28 \mathrm{~g} \mathrm{l}^{-1}$ dry biomass from root systems of Johnson grass and can be arranged in the following order: soybean $\rightarrow$ peas $\rightarrow$ vetch. Keywords: allelopathy, extract, Johnson grass, peas, roots, seeds, Sorghum halepense (L.) Pers., soybeans, vetches
\end{abstract}

\section{Introduction}

Studies of plant communities are often closely connected with the problems of interspecific relations between crops and weeds. The relatively low competitive ability of soybean, peas and vetch at the early stages of growth determine the weeds as a factor inhibiting the yield per grain (Marinov-Serafimov \& Dimitrova, 2007).

The studies conducted so far (Hoque et al., 2003, Marchin-Silva \& Aquila, 2006, Stoimenova et al., 2008) have demonstrated that many of the weed species accumulated both in their roots and shoots water soluble inhibitory substances that, after washing, evaporation and decomposition of the plant remain, spread in the environment and thus inhibit the seed germination of a large number of crops. Other studies present different

S. Kalinova • A. Hristoskov

Agricultural University, Mendeleev 12, 4000 Plovdiv, Bulgaria

I. Golubinova* • A. Ilieva

Institute of Forage Crops, Gen. Vladimir Vazov 89,

5800 Pleven, Bulgaria

e-mail: golubinova@abv.bg rates of inhibitory or stimulating effect of the studied weed species on the seed germination of crops (Kadioglu et al., 2005, Marinov-Serafimov, 2005, Marinov-Serafimov, 2010).

The interaction between weeds and cultivated plants is simultaneous and/or subsequent with direct or indirect impact of one plant species on another, through synthesis of different chemical compounds (allelochemicals) that are released in the environment and have an inhibitory and/ or stimulatory effect on the seed germination and development of crops (Verma \& Rao, 2006, Aleksieva \& Serafimov, 2008). Number of studies (Vasilakoglou et al., 2006, Ashrafi et al., 2007, Koloren, 2007) determined allelopathic interaction between weeds and crops using plant material extracted from the dry weed biomass. The lack of similar studies in Bulgaria motivated our interest to determine the allelopathic effect of root systems of Johnson grass on some legume plants.

Acknowledgement: This study is an integral part of the Project TR 31028, entitled "Maize genetic resources as a source of improved grain quality and drought tolerance" financed by the Ministry of Education, Science and Technological Development of the Republic of Serbia. 
The purpose of the study was to determine the allelopathic effect of root systems of Johnson grass on seed germination and initial plant development in agrophytocoenoses of soybean, peas and vetch. The interdependences in the allelopathic relations between the Johnson grass and the crops in the studied plant communities would be an important element of the theoretic base for sustainable plant production. Furthermore, the results of such study would provide additional information about the indirect harmful effect of Johnson grass on the normal growth and development of the plants in beans agrophytocoenoses.

\section{Material and Methods}

The study was conducted in 2010 under laboratory conditions at the Institute of Forage Crops in Pleven, Republic of Bulgaria. Seeds of the following legumes were tested: soybean (Glycine $\max (\mathrm{L}$.$) Merr.), Srebrina variety; pea$ (Pisum sativum (L.)), Pleven variety and vetch (Vicia sativa (L.), Obrazets 666 variety.

Collection of the plant material: The root systems of Johnson grass were taken from depth of 0 to 30 $\mathrm{cm}$ at weed phenophase 71 (Weber \& Bleiholder, 1990) in experimental areas sown with medium early potatoes from the Sante and Fontane varieties, with natural weeding background, at the experimental field of the General agriculture and Herbology Department at the Agricultural University of Plovdiv, Republic of Bulgaria.

Preparation of weed extracts: The root systems of Johnson grass were chopped in pieces between 0.5 and $3.0 \mathrm{~cm}$ long, dried to obtain constant dry mass at $55 \pm 3^{\circ} \mathrm{C}$ and then ground in a Retsch SM-1 grinder with $1.0 \mathrm{~mm}$ sieve size. Portions of $100 \mathrm{~g}$ dry biomass from the Johnson grass roots were soaked in 11 of distilled water. The obtained samples were then cold extracted at 24 $\pm 2^{\circ} \mathrm{C}$ for $8 \mathrm{~h}$ in a Shuttle decanter at $120 / 60$ $\mathrm{s}^{-1}$. The obtained extract was then taken out from the decanter, filtered and centrifuged in a K24 centrifuge at 5000/60 $\mathrm{s}^{-1}$. The aqueous extracts were brought to $12.5 ; 25.0 ; 50.0$ and $100.0 \mathrm{~g}$ dry biomass content per $1 \mathrm{l}^{-1}$ of distilled water (hereinafter designated as $\mathrm{g} \mathrm{l}^{-1}$ ). Thymol $\left(\mathrm{C}_{10} \mathrm{H}_{14} \mathrm{O}\right)$ as preservative was added to each of the extracts (Marinov-Serafimov et al., 2007a).

Bioassays technique: Batches of 100 seeds of soybean, peas and vetch were placed between layers of filter paper in plastic containers in four replications. The surface of the seeds was sterilized following the method of Voll et al. (2005). All of the available extracts ranging by root biomass content were pipetted in a proportion of $1: 6$ to the seed mass (Marinov-Serafimov et al., 2007b), and distilled water was used as control. Each variant was laid out in six replications. The samples were placed in a thermostatic device at $22 \pm 2^{\circ} \mathrm{C}$ for 7 days. A biochemical analysis of the roots was performed for content of: cyanogenic glucosides (Ermakov et al., 1987), total phenols (Swain \& Hillis, 1959), trypsin inhibitory activity (Page et al., 2000), condensed tannins (Terril et al., 1992) and water soluble sugars (Ermakov et al., 1987).

The following characteristics were determined: Percentage of germinated seeds (\%); Germ length at phenophase 08 of the development of soybean, peas and vetch $(\mathrm{cm})$ according to Weber \& Bleiholder (1990); Inhibition Rate (IR) at seed germination and at germ growth calculated according to the formula of Ahn \& Chung (2000).

SPEARMAN estimates software (Hamilton et al., 1978) was used to determine the $\mathrm{LC}_{50}$ of the extract in the test samples. The index of initial growth (GI) of the plants was determined using the formula of Gariglio et al. (2002). The growth rate $\left(\mathrm{K}_{\mathrm{cm}}\right)$ and the biomass accumulation rate $\left(\mathrm{K}_{\mathrm{g}}\right)$ of the germ were calculated using the formula of Mamonov \& Kim (1978). The acidity of the solutions was measured using Gallenkamp pH stick.

The experimental data were statistically processed after transformation of the percentage of germinated seed by the formula $Y=\arcsin \sqrt{\left(x_{\%} / 100\right)}$ (Hinnkelmann \& Kempthorne, 1994). All experimental data were statistically processed using the Statgraphics Plus for Windows Version 2.1 software.

\section{Results and Discussion}

The aqueous extracts from the roots of Johnson grass inhibited the germination of the seeds of soybean, peas and vetch at rates between $28.8 \%$ and $86.3 \%$, the differences being statistically proven at $\mathrm{P}=0.01$. The rate of inhibition (IR) of the germination of seeds of soybean, peas and vetch at different concentrations of the Johnson grass roots extract varied in a wide range between $15.8 \%$ and $62.8 \%$ compared to the control sample (Table 1). 
Table 1. Effect of aqueous extracts from roots of Johnson grass on seed germination in test plants

\begin{tabular}{|c|c|c|c|c|c|c|c|c|c|c|c|c|}
\hline \multirow{4}{*}{$\begin{array}{l}\text { Weed } \\
\text { biomass in } \\
\text { the water } \\
\text { extracts, } \\
\mathrm{g} \mathrm{l}^{-1}\end{array}$} & \multicolumn{12}{|c|}{ Species } \\
\hline & \multicolumn{3}{|c|}{ Glycine max } & \multicolumn{3}{|c|}{ Pisum sativum } & \multicolumn{3}{|c|}{ Vicia sativa } & \multicolumn{3}{|c|}{ Average } \\
\hline & \multicolumn{12}{|c|}{ Characteristics } \\
\hline & $\mathrm{N}$ & $\%$ & IR & $\mathrm{N}$ & $\%$ & IR & $\mathrm{N}$ & $\%$ & IR & $\mathrm{N}$ & $\%$ & IR \\
\hline 0 & 63.4 & 100 & 0.0 & 65.9 & 100 & 0.0 & 61.1 & 100 & 0.0 & 63.5 & 100 & 0.0 \\
\hline 12.5 & 54.7 & $86.3^{\text {蛙 }}$ & 13.7 & 52.7 & $80.0^{\text {蚝 }}$ & 20.0 & 52.7 & $86.3^{\text {拉 }}$ & 13.7 & 53.4 & 84.2 & 15.8 \\
\hline 25 & 54.7 & $86.3^{\text {辣 }}$ & 3.7 & 50.8 & $77.0^{\text {辣 }}$ & 23.0 & 37.3 & $61.0^{\ddagger \neq ⿱ 亠 䒑 十 ⿻}$ & 9.0 & 47.6 & 74.8 & 11.9 \\
\hline 50 & 50.8 & $80.0^{\text {辣 }}$ & 0.0 & 33.2 & $50.4^{\text {牶 }}$ & 49.6 & 32.2 & $52.6^{6^{\ddagger} \neq}$ & 47.4 & 38.7 & 61.0 & 32.3 \\
\hline 100 & 31.0 & $49.0^{\text {辣 }}$ & 51.0 & 21.4 & $32.5^{\text {辣 }}$ & 67.5 & 18.4 & $30.2^{2^{\ddagger \ddagger}}$ & 69.8 & 23.6 & 37.2 & 62.8 \\
\hline
\end{tabular}

Legend: $N$-number of germinated seeds; \%-percentage compared to control; IR-rate of inhibition of seed germination, \%; $\neq$ statistically proven differences at $t_{\text {critical }} P_{0.5}=2.0 ; P_{0.1}=2.7 ; P_{0.01}=3.6$

Concerning the impact of the Johnson grass root content in the aqueous solutions $\left(\mathrm{g} \mathrm{l}^{-1}\right)$, it was found that with increasing concentrations of weed biomass the percentage of germinated seeds decreased non-proportionally (from $84.2 \%$ to $37.2 \%)$ on average in all test plants, the differences being statistically proven at $\mathrm{P}=0.01$ (Table 1).

This interdependence could be explained by the presence of cyanogenic glycosides and general phenols, as well as the complex impact of water soluble sugars contained in the tested extracts (Table 2).

It is well known that cyanogenic glycosides and phenols are highly toxic and have pronounced protoplasmic effect (Iqbal et al., 2003). In higher concentrations, they may have a lethal impact on the seed germination whereas in lower concentrations they inhibit their germination to different degrees, which is probably due to the lower glycoalkaloid and phenol content.

The determination of the rate of inhibition (IR) of the seed germination in the tested beans gave the same results. In accordance with these results, the tested crops could be divided into two groups. The first group comprises of the soybean the seed germination of which is inhibited up to $25 \%$. To the second group belong the peas and the vetch the seed germination of which is inhibited between $35 \%$ and $40 \%$ (Table 1). Obviously, the tested beans react in different ways to the inhibitory effect of the aqueous extracts from roots of Johnson grass. The seeds of pea and of the vetch are much more sensitive than the seeds of soybean (Table 1).

The different inhibitory effects of the extracts from roots of Johnson grass on the seed germination in the test plants can by explained on the one hand by the diffusion of the soluble allelochemicals during extraction of the biomass (Jiménez-Osornio et al., 1996, Cheema, 1998) and on the other hand by the different raw protein content in the seeds of soybean, pea and vetch (Kertikov, 2005, Marinov-Serafimov, 2005, Stoimenova et al., 2008). Similar results were reported by Marinov-Serafimov et al. (2007b) who determined the inhibitory effect of aqueous extracts from weeds typical of the biocoenoses of soybean, pea and vetch.

Table 2. Biochemical analysis of roots of Johnson grass

\begin{tabular}{ccccc}
\hline \multicolumn{4}{c}{ Parameters } \\
\hline $\begin{array}{c}\text { Cyanogenic glycosides } \\
\left(\mathrm{mg} \mathrm{HCH} / 100 \mathrm{~g}^{-1}\right)\end{array}$ & $\begin{array}{c}\text { Total phenols } \\
(\text { relative units extinction) }\end{array}$ & $\begin{array}{c}\text { Condensed } \\
\text { tannins } \\
(\%)\end{array}$ & $\begin{array}{c}\text { Tripsin inhibitor } \\
\text { activity } \\
\left(\mathrm{TIU} / \mathrm{mg}^{-1}\right)\end{array}$ & $\begin{array}{c}\text { Water soluble } \\
\text { sugars content } \\
(\%)\end{array}$ \\
\hline 16.48 & 0.674 & 0.0 & 1.43 & 15.6 \\
\hline
\end{tabular}


Furthermore, analogous results were obtained while determining $\mathrm{LC}_{50(\mathrm{P}=0.5)}$ on the germination of seeds of soybean, pea and vetch depending on the inhibitory effect of the extracts from roots of Johnson grass. The values of $\mathrm{LC}_{50(\mathrm{P}=0.5)}$ varied from $46.40 \mathrm{gl}^{-1}$ to $98.28 \mathrm{gl}^{-1}$ and could be conventionally grouped in the following order: soybean $[98.28$ $(-79.44+121.60)] \rightarrow$ pea $[52.97(-42.39+66.19]$ $\rightarrow$ vetch $[46.40(-36.86+58.42)]$. The different values of $\mathrm{LC}_{50}$ could be explained by the different sensitivity of the test plants seeds, which is mainly due to their morphologic particularities.

The aqueous extracts from root systems of Johnson grass had different suppressive effects on the growth of the germ (from $17.1 \%$ to $86.1 \%$ ) and on the accumulation of fresh biomass in the primary seedling (from $8.3 \%$ to $97.9 \%$ ) of soybean, peas and vetch seeds (Table 3). With increase of the concentration of the extracts from root systems of Johnson grass, the growth and the accumulation of fresh biomass in the primary seedling of all test plants decreased disproportionately compared to the control, the differences being statistically proven at $\mathrm{P}=0.05$.

Similar were the results about the growth rate and the rate of accumulation of fresh biomass in the primary seedlings of soybean, pea and vetch seeds depending on the concentration of the water root extracts (Table 3).

The growth rate of the seedling $(\mathrm{K} / \mathrm{cm})$ and the rate of accumulation of fresh biomass in the seedling $(\mathrm{K} / \mathrm{g})$ of the studied crops also seemed to depend on the concentration of the extract from Johnson grass. In all three crops relatively smaller inhibition of the growth rate of the seedling $(\mathrm{K} /$ $\mathrm{cm})(\mathrm{r}$ varied in the range from -0.676 to -0.788$)$ and greater inhibition of the rate of accumulation of fresh biomass $(\mathrm{K} / \mathrm{g})$, where $\mathrm{r}$ varied from -0.896 to -0.938 - were found (Figures 1 and 2).

According to Iman et al. (2006), the mechanism of inhibition of the growth and of the accumulation of fresh biomass in the primary seedling of the seeds results from the effect of allelochemicals and could be explained by reduced cell division rate and/or by the elongation of the cells. Therefore, the stage of germination of the seeds can be considered as a less sensitive period in the individual development of the plants while the growth of the primary seedling could be used as a potential test to determine the allelopathic effect of the studied extract under laboratory conditions due to the direct contact of the extracts during the bioassays.

Table 3. Effect of aqueous extracts from Johnson grass roots on the growth rate and the accumulation of fresh biomass in the seedlings of test plants

\begin{tabular}{|c|c|c|c|c|}
\hline \multirow{2}{*}{$\begin{array}{l}\text { Weed biomass in the water } \\
\text { extracts }\left(\mathrm{g}^{-1}\right)\end{array}$} & \multicolumn{4}{|c|}{ Species } \\
\hline & Glycine max & Pisum sativum & Vicia sativa & Average \\
\hline \multicolumn{5}{|c|}{ Length of seedlings $\left(\mathrm{cm}\right.$ plant $\left.\mathrm{t}^{-1}\right)$} \\
\hline 0 & $11.0 \mathrm{~d}(0.0)^{*}$ & $9.6 \mathrm{~d}(0.0)$ & $10.5 c(0.0)$ & $10.4 \mathrm{~d}(0.0)$ \\
\hline 12.5 & $9.1 \mathrm{c}(17.1)$ & $6.6 \mathrm{~cd}(31.4)$ & $6.4 \mathrm{~b}(39.2)$ & $7.4 \mathrm{~cd}(29.2)$ \\
\hline 25 & $8.7 c(21.3)$ & $5.1 \mathrm{bc}(46.7)$ & $3.7 \mathrm{a}(65.0)$ & $5.8 \mathrm{bc}(44.3)$ \\
\hline 50 & $6.3 \mathrm{~b}(42.9)$ & $3.3 \mathrm{ab}(65.9)$ & $2.8 \mathrm{a}(72.9)$ & $4.1 \mathrm{ab}(60.6)$ \\
\hline 100 & $2.9 \mathrm{a}(74.1)$ & $1.3 \mathrm{a}(86.1)$ & $1.8 \mathrm{a}(83.1)$ & $2.0 \mathrm{a}(81.1)$ \\
\hline \multicolumn{5}{|c|}{ Fresh biomass of seedlings ( $\mathrm{g}_{\text {plant }} \mathrm{t}^{-1}$ ) } \\
\hline 0 & $0.33 c(0.0)$ & $0.24 \mathrm{c}(0.0)$ & $0.10 \mathrm{~d}(0.0)$ & $0.22 \mathrm{~b}(0.0)$ \\
\hline 12.5 & $0.29 \mathrm{~b}(11.2)$ & $0.22 c(8.3)$ & $0.06 c(40.4)$ & $0.19 \mathrm{ab}(20.0)$ \\
\hline 25 & $0.23 b(28.6)$ & $0.18 \mathrm{~b}(26.4)$ & $0.06 c(40.4)$ & $0.16 \mathrm{ab}(31.8)$ \\
\hline 50 & $0.23 b(29.6)$ & $0.10 \mathrm{ab}(59.0)$ & $0.03 \mathrm{~b}(64.5)$ & $0.12 \mathrm{ab}(51.0)$ \\
\hline 100 & $0.04 a(87.1)$ & 0.005a (97.9) & $0.009 \mathrm{a}(91.0)$ & $0.02 \mathrm{a}(92.0)$ \\
\hline
\end{tabular}

Legend: $a, b, c, d$, are statistically proven differences in $P=0.05 ;{ }^{*}$ Degree of inhibition in the germination of respective control, \% 


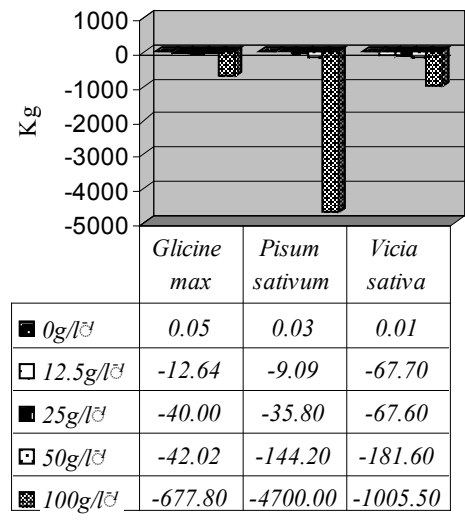

Figure 1. Effect of aqueous extracts from roots of Sorghum halepense (L.) Pers. on the rate of accumulation $\left(\mathrm{K}_{\mathrm{g}}\right)$ of fresh biomass in the seedling of test plants.

The experimental data confirm the findings of other authors (Cheema, 1998, Turk \& Tawaha, 2002, Ashrafi et al., 2007), namely the effect of allelochemicals is manifested in the germination inhibition, but it is more pronounced on the growth of the seedlings.

The index of initial growth of the plants (GI) depends on the same factors and follows the observed interdependences as concerns the seed germination and the growth of the primary seedling in the test plants under laboratory conditions (Table 4).

The results from the laboratory analyses show that the studied extracts from roots of Johnson grass have a delaying and/or inhibitory effect on the initial growth of soybean, pea and vetch. With increase of the dry biomass from roots of Johnson grass in the aqueous extracts the initial plant growth index (GI) decreased by $40.4 \%$ and $92.2 \%$. Hence, the differences observed in the studied bean crops in respect of the allelopatic effect of the extracts could also be explained

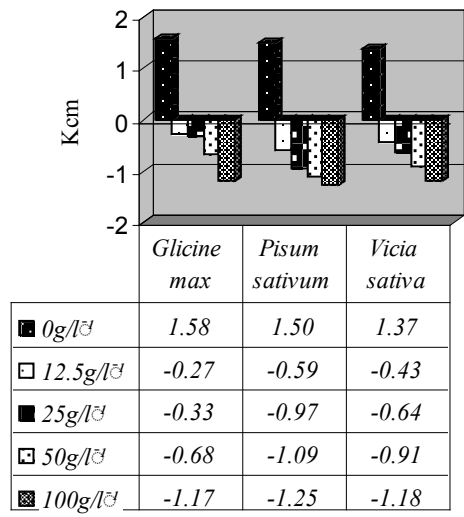

Figure 2. Effect of aqueous extracts from roots of Sorghum halepense (L.) Pers. on the growth rate $\left(\mathrm{K}_{\mathrm{cm}}\right)$ of the seedling in test plants

by the morphologic and biological differences between them since the comparisons were made in identical conditions and with the same concentrations of the extracts applied.

The germination of the seeds of soybean, pea and vetch also depended on the acidity of the extracts, which varied between 5.5 and 6.9. A strong positive correlation was discovered between the germination of the seeds of soybean, pea and vetch and $\mathrm{pH}$ of the extracts where $\mathrm{r}$ varied between 0.932 and 0.974 .

Furthermore, the effect of the extracts on the germination of seeds of soybean, pea and vetch can be expressed as function of the oxidation processes for extracts made from dry biomass of roots of Johnson grass in the following order: soybean $-[$ Germination $=1 /(0.222129$ 0,001327463. $\mathrm{pH}) ; \mathrm{R}^{2}=0.944$; St. error 0.0062]; pea [Germination $=1 /(0.19742-0,000897213$. $\mathrm{pH}) ; \mathrm{R}^{2}=0.930$; St. error 0.0050] and vetch $[$ Germination $=1 /(0.19322-0,000892291 . \mathrm{pH})$; $\mathrm{R}^{2}=0.856$; St. error 0.0049].

Table 4. Effect of aqueous extracts from roots of Johnson grass on the initial growth (GI) of the test plants

\begin{tabular}{lccccc}
\hline \multirow{2}{*}{ Species } & \multicolumn{5}{c}{ Weed biomass in the water extracts $\left(\mathrm{g} \mathrm{l}^{-1}\right)$} \\
\cline { 2 - 6 } & 0 & 12.5 & 25 & 50 & 100 \\
\hline Glycine max & 100 & 71.5 & 67.9 & 45.7 & 12.7 \\
Pisum sativum & 100 & 54.9 & 41.0 & 17.2 & 4.5 \\
Vicia sativa & 100 & 52.5 & 21.4 & 14.3 & 6.1 \\
\hline Average & 100 & 59.6 & 43.4 & 25.7 & 7.8 \\
\hline
\end{tabular}




\section{Conclusions}

Aqueous extracts from the roots of Johnson grass inhibited the germination of soybean, pea and vetch. Inhibitory effect varied between 28.8 and $86.3 \%$, the differences being statistically proven at $\mathrm{P}=0.01$.

Aqueous extracts from the roots of Johnson grass have suppressive effect on the seedling growth (from $17.1 \%$ to $86.1 \%$ ) and the fresh biomass of seedlings (from $8.3 \%$ to $97.9 \%$ ) of soybean, pea and vetch. The values of $\mathrm{LC}_{50}$, which vary from $46.40 \mathrm{~g} \mathrm{l}^{-1}$ to $98.28 \mathrm{~g} \mathrm{l}^{-1}$ of fresh biomass from roots of Johnson grass, can be arranged in the following order: soybean $\rightarrow$ pea $\rightarrow$ vetch.

\section{References}

Ahn, J., \& Chung, I. (2000). Allelopathic potential of rice hulls on germination and seedling growth of Barnyardrass. Agronomy Journal, 92, 1162-1167.

Aleksieva, A., \& Serafimov, Pl. (2008). A study of allelopathic effect of Amaranthus retroflexus (L.) and Solanum nigrum (L.) in different soybean genotypes. Herbologia, 9, 47-58.

Ashrafi, Z., Mashhadi, H., \& Sadeghi, S. (2007). Allelopathic effects of barley (Hordeum vulgare) on germination and growth of wild barley (Hordeum spontaneum). Pakistan Journal of Weed Science Research, 13, 99-112.

Cheema, Z. (1998). Sorghum allelopathy a new weed control technology for enhancing wheat productivity. Journal of Animal and Plant Sciences, 8, 19-21.

Ermakov, A., Arassimovich, V., Yarosh, N., Perouanskii, Y., Lukovnikova, G., \& Ikonnikova, M. (1987). Methods of biochemical studies of plants. Leningrad: Agropromizdat, (in Russian).

Gariglio, N., Buyatti, M., Pillati, R., Rossa, D., \& Acosta, M. (2002). Use of a germination bioassay to test compost maturity of willow (Salix spp.) sawdust. New Zealand Journal of Crop of Horticultural Science, 30, 135-139.

Hamilton, M., Russo, R., \& Thurston, R. (1978). Trimmed Spearman-Karber method for estimating median lethal concentrations in toxicity bioassays. Environmental Science and Technology, 11, 714-719.

Hinnkelmann, K., \& Kempthorne, O. (1994). Design and analysis of experiments. Vol. 1, Wiley and Sons, New York.

Hoque, A., Romel, A., Uddin, M., \& Hossain, M. (2003). Allelopathic effects of different concentration of water extracts of Eupatorium odoratum leaf on germination and growth behavior of six agricultural crops. Journal of Biological Sciences, 3, 741-750.

Iman, A., Wahab, S., Rastan, M., \& Halim, M. (2006). Allelopathic effect of sweet corn and vegetable soybean extracts at two growth stages on germination and seedling growth of corn and soybean varieties. Journal of Agronomy, 5, 62-68.

Iqbal, Z., Hiradate, S., Noda, A., Isojima, S., \& Fujii, Y. (2003). Allelopathic activity of buckwheat: isolation and characterization of phenolics. Weed Science, 51, 657-662.

Jiménez-Osornio, F., Kumamoto, J., \& Wasser, Ch. (1996). Allelopathic activity of Chenopodium ambrosioides L. Biochemical Systematics and Ecology, 24, 195-205.
Kadioglu, I., Yanar, Y., \& Asav, U. (2005). Allelopathic effects of weeds extracts against seed germination of some plants. Journal of Environmental Biology, 26, 169-73.

Kertikov, T. (2005). Comparative characterization of economic and qualitative indices in two varieties of spring vetch (Vicia sativa L.). Bulgarian Journal of Agricultural Science, 11, 475-481.

Koloren, O. (2007). Allelopathyc effects of Medicago sativa L. and Vicia cracca L. leaf and root extracts on weeds. Pakistan Journal of Biological Science, 10, 1639-1642.

Mamonov, L., \& Kim, G. (1978). Mathematical modeling of physiological processes of plants. Alma-Ata, Publishing House "Nauka" (in Russian).

Marchin-Silva, F., \& Aquila, M. (2006). Contribution to the study of native species allelopathic potential, Rev. Árvore, 30, 4.

Marinov-Serafimov, P. (2005). Study on the competitive relationship between soybean and black nightshade (Solanum nigrum L.) under conditions of leached black earth in northern Bulgaria (Doctoral dissertation).

Marinov-Serafimov, P., \& Dimitrova, Ts. (2007). Dynamics and distribution of the main weeds in weed associations of some grain legume crops. Plant Science, 44, 167-173.

Marinov-Serafimov, P., Dimitrova, Ts., Golubinova, I., \& Ilieva, A. (2007a). Study of suitability of some solutions in allelopathic researches. Herbologia, 8, 1-10.

Marinov-Serafimov, P., Dimitrova, Ts., \& Golubinova, I. (2007b). Study of water imbibing capacity of some legume crops under in vitro conditions in allelopathic research. Herbologia, 9, 29-40.

Marinov-Serafimov, P. (2010). Determination of allelopathic effect of some invasive weed species on germination and initial development of grain legume crops. Pesticides \& Phytomedicine (Belgrade), 25, 251-259.

Page, D., Quillien, L., \& Doc, G. (2000). Trypsin inhibitory activity measurement: simplifications of the standard procedure used for pea seed. Crop Science, 40, 1482-1485.

Stoimenova, I., Mikova, A., \& Aleksieva, S. (2008). Influence of allelopathy and weed infectation on crop growing. Selskostopanska Nauka / Agricultural Science, 41(3), 3-13.

Swain, T., \& Hillis, W. (1959). The phenolic constituents of Prunus domestica. Journal of the Science of Food and Agriculture, 10, 63-68.

Terrill, T., Rowan, A., Douglas, G., \& Barry, T. (1992). Determination of extractable and bound condensed tannin concentrations in forage plants protein concentrate meals and cereal grains. Journal of the Science of Food and Agriculture, 58, 321-329.

Turk, M., \& Tawaha, A. (2002). Inhibitory effects of aqueous extracts of black mustard on germination and growth of lentin. Pakistan Journal of Agronomy, 1, 28-30.

Vasilakoglou, I., Dhima, K., Eleftherohorinos, I., \& Lithourgidis, A. (2006). Winter cereal cover crop mulches and inter-row cultivation effects on cotton development and grass weed suppression. Agronomy Journal, 98, 1290-1297.

Verma, M., \& Rao, P. (2006). Allelopathic effect of four weed species extracts on germination, growth and protein in different varieties of Glycine max (L.) Merrill. Journal of Environmental Biology, 27, 571-577.

Voll, E., Voll, C. E., \& Filho, R. V. (2005). Allelopathic effects of aconitic acid on wild poinsettia (Euphorbia heterophylla) and morningglory (Ipomoea grandifolia). Journal of Environmental Science and Health, Part B, 40(1), 69-75.

Weber, E., \& Bleiholder, H. (1990). Erläuterungen zu den $\mathrm{BBCH}$-Dezimal-Codes fürdie Entwicklungsstadien von Mais, Raps, Faba-Bohne, Sonnenblume und Erbse - mit Abbildungen. Gesunde Pflanzen, 42, 308-321. 


\section{Alelopatski efekat vodenog ekstrakta iz korenskog sistema divljeg sirka na klijavost semena i početni razvoj soje, graška i grahorice}

\section{Shteliyana Kalinova • Irena Golubinova • Angel Hristoskov • Anna Ilieva}

Izvod: U ovom radu se predstavljeni rezultati istraživanja alelopatskog efekta hladnog vodenog ekstrakta iz korenovog sistema divljeg sirka (Sorghum halepense (L.) Pers.) na klijavost semena i početni razvoj soje (Glycine max (L.)), graška (Pisum sativum (L.)) i grahorice (Vicia sativa (L.)) pod laboratorijskim uslovima. Utvrđen je raspon inhibitornog efekta vodenog korenskog ekstrakta na klijavost semena soje, graška i grahorice od 28,8\% do 86,3\%. Takođe, inhibitorni efekat vodenog korenovog ekstrakta divljeg sirka na razvoj inicijalne klice ovih vrsta varirao je u rasponu $17,1-86,1 \%$ a na akumulaciju sveže biomase u inicijalnoj klici u rasponu 8,3-97,9\%. Utvrđene su vrednosti $\mathrm{LC}_{50(\mathrm{P}=0.05)}$ koje variraju između 46,40 i 98,28 $\mathrm{g} \mathrm{l}^{-1}$ suve biomase iz korenovog sistema divljeg sirka i mogu se postaviti u sledećem redosledu: soja $\rightarrow$ grašak $\rightarrow$ grahorica.

Ključne reči: alelopatija, divlji sirak, ekstrakt, grahorica, grašak, koren, seme, soja, Sorghum halepense (L.) Pers. 